\title{
How do Muslim States Treat their "Outsiders"?: Is Islamic Practice of Naturalisation Synonymous with Jus Sanguinis?
}

\author{
Radhika Kanchana
}

Ahmad al-Tayyib, the Grand Imam of the renowned Al-Azhar Sunni Arab institution of learning in Egypt, made four points at the Islamic-Christian conference in Cairo (28 Feb-1 Mar 2017). This came to be called the Al-Azhar Declaration, which asserted that Islam is compatible with religious pluralism. He upheld the principle of equality of rights and duties for both Muslims and non-Muslims within a "national constitutional state." He insisted that the concept of "citizenship" was part of the foundations of Islam, citing reference to the Prophet's Constitution of Medina in the first Muslim society.

The Al-Azhar Declaration challenges the prevailing popular perception that Muslim countries are relatively closed societies, especially in relation to nonMuslims in their territory. Islam's principles supposedly do not live easily with contemporary international law and norms that demand, for example, more secular and egalitarian values and institutions. The present paper concerns the treatment of "the other" by focusing on the practice of naturalisation in states with majority Muslim population or states that define themselves as Islamic. How states deal with foreigners who eventually become residents is an important question in the discussion on ethics relating to migration. This preliminary research is part of a broader project to empirically explore the subject. It concerns the practice of Muslim states on naturalisation since the mid-twentieth century, to see whether the Jus sanguinis citizenship principle is generally a "by default" occurrence, or if they show other nuanced arrangements in law and policy.

The focus is on Jus sanguinis to ascertain the potential access of foreigners, especially non-Muslim, to acquire citizenship and ensuing rights in Muslim countries. Individuals are granted citizenship of a nation either Jus soli (those that are born there and automatically acquire the status), or Jus sanguinis where one or both parents are citizens. Alternatively, they can acquire citizenship by a deliberate process - through naturalisation. Naturalisation is a key 
mechanism by which a state either facilitates or blocks the incorporation of new candidates for citizenship. Thus, the content of the national provisions to grant access to naturalisation is important. A society's degree of access to citizenship shows its level of inclusiveness or exclusiveness. Jus soli and Jus sanguinis are the two dominant regimes that inform states' choice in granting citizenship. Jus soli ascribes citizenship automatically to everyone born on the territory: the USA is a primary example of a liberal Jus soli. Jus sanguinis ascribes citizenship automatically to individuals born to parent/s that are citizens of the state. It is also known as the citizenship "by descent," meaning via blood or ethnic affiliation. Many states follow a combination of the two, roughly termed as Jus domicile. Jus sanguinis becomes particularly relevant when the naturalisation criteria over-emphasize this principle for the allocation of citizenship. In effect, this restricts state membership with the stress on ties before birth.

I approach naturalisation and the access to citizenship in this paper as the progressive process for an individual to belong and to consolidate rights in the local society where he/she resides, irrespective of prior or current affiliations. The concept of citizenship, broadly constituting three key dimensions namely legal status, participation and membership of an individual in a political community, is itself far from frozen. It is evolving - in its definition, the specific rights and duties it entails and the regulating institutions. States with majority Muslim populations or that follow Islamic law similarly experience new articulations of citizenship. For instance, Kiwan observes that the Arab uprisings from 2011 demonstrate reformulations of citizenship identities $(2005,311)$ : "Emerging constructions of citizenship across the Arab world are being 'reimagined' in relation to intersecting identities of ethnicity, religion and nationality, as well as age, gender, and socio-economic status." She refers here to the disaffected youth, the women, the Islamists stepping in to close the gap left by the non-performing regimes, and the refugees.

More scholarship exists on Muslims' integration or as minorities in the mainly Christian and Western democracies. Much less scholarship has been forthcoming in the converse case regarding non-Muslims in Muslim states from the perspective of Islamic law and empirical studies. Contemporary Muslim states generally follow the Jus sanguinis principle for citizenship. While "democratic citizenship" in the dominant parlance allegedly does not find an easy resonance in Islam, Islamic law has traditionally allocated a secondary status of dhimmi to the non-Muslim, most evident in the millet system of the Ottoman period. The objective here is to investigate how "open" is the gate of citizenship to the outsider in contemporary Muslim states, from the background of Islamic doctrine, existing international norms and contemporary practice. 
The paper looks at the naturalisation provisions of 18 Muslim states with attention to their historical and socio-political factors. It first observes the general trend of the naturalisation provision to foreigners in a cross-section of Muslim states and then in the six Arab-Gulf states in closer detail (Oman, Saudi Arabia, the UAE, Qatar, Bahrain and Kuwait), drawing from my dissertation research (Kanchana 2016).

\section{Membership of the Other in an Islamic Society}

Muwattana is the nearest term in Islamic texts that best resonates with the concept of citizenship, in the sense of "democratic citizenship" as we widely understand it (Parolin 2009). Whereas, Jinsiyya, something like a nationality certificate (Davis 1995) and Wataniyya, or nationalism in the Western sense, i.e., attachment to a territorialized sovereign nation-state (Longva 1995: 214) are two other terms with similar connotation that often cause confusion. Thus, muwattin is a citizen in the legal sense. There is allegedly a discord with this concept in Islam. For example, Fetni (in Ciprut 2008) argues that "citizenship" does not exist in "traditional" Islam, as a relationship between the individual and the state. She instead proposes the notion of "Islamic citizenship" resembling a club, where membership is through the faith because the idea of "individual" does not exist in the "umma" or the collective ethos: "Islam is a din wa dawla. That is, religion and state go together in the goal to better propagate Islam or the message of peace and warning. Therefore, "membership" is exclusive to the faith-community, making non-Muslims the outsiders by default.

However, Islam concedes protection and rights to non-Muslims based on their residence status in an Islamic territory. Early Islamic dogma famously recognized and accepted, although in a somewhat qualified manner, religious pluralism in Islamic societies by giving Jews and Christians freedom to practice their religion. Islam also provided for crossing ethnic lines. For instance, Arabs, Kurds, Berbers and Turks who were fused together within a global and universal Islamic community (umma), have acted as its political leaders in the past (Shatzmiller 2005: 285).

Islam in the written text officially relegates non-Muslims living in dār alIsläm (or lands under the Islamic rule) to the status of dhimmi. Under the Islamic law, or the Shari'a, which directs the social behaviour of individuals in an Islamic society, the Qãdis or judges granted this alternative dhimmi status. The status applies only to the ahl al-kitāb ("People of the Book") who also followed religions with divinely revealed scriptures - in other words, with 
monotheistic beliefs like the Jews, the Șabians of Harran and the Christians (the kitābis). The non-Muslim could remain within their own religious community both physically and under their own laws and regulations. The dhimmi (under the "protected" status) and the mustamin (allowed to conduct business) were foreigners in an intermediate category, between a believer and a non-believer. The millet system in the Ottoman period during the late Middle Ages was a clear example, which legally defined and protected religious minorities within the empire:

In exchange for official tolerance and legal recognition under the law, all male, free, and sane dhimmis were required to pay a poll tax (jizya) and those who were land- and property-owners were also obligated to pay the tax known as kharāj. (Martin in Shatzmiller 2005: 5)

Religious pluralism thus existed in the normative sense in Islamic societies and elsewhere, like the pre-colonial Muslim-ruled states in India. In social reality, the dhimmis under the Ottomans appear to have enjoyed fair treatment if they did not contest the preponderance of the Muslims. "Dhimmis were granted independence in the practice and maintenance of their own religious and social affairs so long as they did not impinge upon Muslims" (Martin in Shatzmiller 2005: 5). In this sense, they were second-class citizens. Hourani (1947) noted that nationality was a less important marker than religion, language and ethnicity in his identification of thirty-one minority groups in the Middle East.

However, tradition or religious text alone did not influence all the Muslim states in an identical fashion, even in specific domains like legal practice. The Pew report (2013) observed that modern-day states, which favoured applying the Shari'a especially to family law ("for human relations of a private and familial nature," such as marriage and inheritance) appear in this order: South East Asia, South Asia, the MENA and Central Asia. Fetni (in Ciprut 2008) also highlights the diversity of other examples. For example, Turkey separated with the Shari'a for its national law; the Gulf States as "the new nations in the Arabian Peninsula allowed Shari'a law to remain practically intact'; and most states in the larger trend adopted a combination of the Western legal system and the Shari'a. Therefore, multiple factors are needed to explain the varied trajectory of the Muslim states concerning citizenship allocation practice; these can include indigenous legal and political cultures, postcolonial contexts, experiences under communist rule and secularisation (such as in Central Asia and Eastern Europe). The Ottoman law of 1869 was the first nationality law 
that set the precedent concerning citizenship, allegedly inspired from the French law of $185^{1}$ (Parolin, 78$)$.

\section{Prominent Evidence of Jus Sanguinis in Muslim States: But Diversity in Context and Application}

In 2017 Kuwait mounted a massive campaign to capture foreigners who had forged citizenship documents. In one case, a Syrian had fraudulently acquired Kuwaiti citizenship 22 years earlier, had enjoyed a job in the public sector and established family with a Kuwaiti wife (Gulfnews: September 19, 2017). Typically, foreigners gave money or entered into an agreement with a Kuwaiti national to obtain forged documents claiming to be a son or member of his family. This enabled him "to obtain a birth certificate, then a national identity card and finally a passport. The Interior Ministry revoked the citizenship of those proven guilty and in some cases also revoked the citizenship of their children. In 2016, the Criminal Court sentenced another Syrian to 15 years in jail, to be followed by deportation and a fine equal to the salaries he received in government job. The Kuwaiti accomplice got 5 years in jail (ibid.).

The several cases of citizenship acquisition through forgery involving nationals in Kuwait might indicate a similar occurrence in the other neighbouring Gulf Cooperation Council (GCC) states, which also impose unusually strict limitations on naturalisation. We will discuss this region later in more detail.

Some of the key problems identified with contemporary Muslim-majority countries such as the high incidence of statelessness and large refugee populations are closely associated with the granting of nationality. In addition to the officially stated naturalisation rules, practices with regard to marriage, adoption and freedom of religion are also relevant for the acquisition of nationality.

The world's Muslim population is geographically spread out, estimated at nearly a quarter of the global population in 2015 (Pew Research Centre 2017). Only about a fifth of the Muslim population lives in the Middle East and the North Africa regions. The largest number lives in the Asia-Pacific region. Indonesia has the highest number, followed by India.

The context is generally harsh for non-Muslims in Muslim countries especially as non-locals or newcomers, to enjoy equal rights in the host countries. At first glance, citizenship allocation in Muslim countries appears to suggest

1 The 1851 reform in France reinstated Jus soli for a child born of foreign parents in France, who themselves were born in the country (double Jus soli). 
that Jus sanguinis is something natural or typical for them, confirming the wide perception that they are conservative societies. This is because predominant Jus sanguinis practice tends to point to closed societies. Muslim countries are presumed to be non-modern societies that explains this highly restricted access to citizenship. To what extent are their citizenship practices similar or antithetical to the more "liberal" practices elsewhere in the world?

The following analysis limits itself to the contemporary practice of Muslim states regarding non-Muslim residents and their access to citizenship, by looking at nationality legislation and the Jus sanguinis principle. First, we note the general trend among a cross-section of selected Muslim states. Next, we will explore the case in the Arab-Gulf states.

The Wider Practice among the Muslim States: Strict Nationality Law Provisions

In contemporary practice, the majority of the Muslim states clearly follow Jus sanguinis combined with a Jus soli variant, but where the stress is on the former (see Table 8.1).

TABLE 8.1 Jus sanguinis in selected muslim-majority states-access to naturalisation in the citizenship policies

\begin{tabular}{|c|c|c|}
\hline $\begin{array}{l}\text { State, } \\
\text { Legislation }\end{array}$ & Jus sanguinis; Jus soli & Naturalisation rules \\
\hline $\begin{array}{l}\text { Morocco } \\
\text { Nationality Code (last } \\
\text { revised 2007) }\end{array}$ & $\begin{array}{l}\text { Jus sanguinis via father (via } \\
\text { mother if father unknown or } \\
\text { stateless); No Jus soli (or if } \\
\text { unknown parents) }\end{array}$ & $\begin{array}{l}\text { Residency } 5 \text { years; Must be } \\
\text { approved by Cabinet } \\
\text { decree; Knowledge of } \\
\text { Arabic }\end{array}$ \\
\hline $\begin{array}{l}\text { Tunisia } \\
\text { Nationality Code } 2011\end{array}$ & $\begin{array}{l}\text { Jus sanguinis via father or } \\
\text { mother; Jus soli if father and } \\
\text { grandfather born in the } \\
\text { country }\end{array}$ & $\begin{array}{l}\text { Residency } 5 \text { years; Knowl- } \\
\text { edge of Arabic; Allows Dual }\end{array}$ \\
\hline $\begin{array}{l}\text { Niger } \\
\text { Nationality Code } 1984\end{array}$ & guinis via father & Residency 10 years \\
\hline $\begin{array}{l}\text { Somalia } \\
\text { Citizenship Law } 1962\end{array}$ & $\begin{array}{l}\text { Jus sanguinis via father (whose } \\
\text { father is Somali); or who is } \\
\text { ethnically Somali }\end{array}$ & $\begin{array}{l}\text { Residency } 7 \text { years; Dual } \\
\text { (2012 Constitution) }\end{array}$ \\
\hline $\begin{array}{l}\text { Turkey } \\
\text { Law } 2009 \text { (revised) }\end{array}$ & $\begin{array}{l}\text { Jus sanguinis via father or } \\
\text { mother; NoJus soli }\end{array}$ & $\begin{array}{l}\text { Residency } 5 \text { years; Knowl- } \\
\text { edge of Turkish }\end{array}$ \\
\hline
\end{tabular}


TABLE 8.1 Jus sanguinis in selected muslim-majority states-access to naturalisation (cont.)

\begin{tabular}{|c|c|c|}
\hline $\begin{array}{l}\text { State, } \\
\text { Legislation }\end{array}$ & Jus sanguinis; Jus soli & Naturalisation rules \\
\hline $\begin{array}{l}\text { Lebanon } \\
\text { Decree No. 15, } 1925 \\
\text { (revised 1960) }\end{array}$ & $\begin{array}{l}\text { Jus sanguinis via father; Jus soli } \\
\text { conditional (of unknown } \\
\text { origin) }\end{array}$ & Residency 5 years \\
\hline $\begin{array}{l}\text { Iraq } \\
\text { Law } 2006\end{array}$ & $\begin{array}{l}\text { Jus sanguinis via father or } \\
\text { mother (if born in Iraq; if born } \\
\text { abroad could apply if father } \\
\text { unknown/stateless or does } \\
\text { not establish filiation) }\end{array}$ & $\begin{array}{l}\text { Residency } 10 \text { years; Doesn't } \\
\text { mention language/ } \\
\text { integration; Excludes } \\
\text { Palestinians; Dual }\end{array}$ \\
\hline $\begin{array}{l}\text { Kazakhstan } \\
\text { Law } 1991 \text { (revised 2013) }\end{array}$ & Jus sanguinis & Residency 5 years \\
\hline $\begin{array}{l}\text { Iran (Islamic Republic of } \\
\text { Iran) } \\
\text { Based on Civil Code } 1928 \\
\text { (revised 2006) }\end{array}$ & $\begin{array}{l}\text { Jus sanguinis via father; Jus soli } \\
\text { conditional (one of the } \\
\text { foreign parents also born in } \\
\text { Iran; born to foreign father to } \\
\text { confirm upon maturity, other) }\end{array}$ & $\begin{array}{l}\text { Residency } 5 \text { years; Other } \\
\text { acquired credit such as } \\
\text { military service, Children } \\
\text { in marriage to Iranian } \\
\text { women; No dual }\end{array}$ \\
\hline $\begin{array}{l}\text { Pakistan } \\
\text { Law } 195^{1}\end{array}$ & $\begin{array}{l}\text { Jus sanguinis via father or } \\
\text { mother; Jus soli }\end{array}$ & $\begin{array}{l}\text { Residence for a continuous } \\
\text { period of one year before } \\
\text { application and a period of } \\
\text { four out of seven years } \\
\text { prior to the one year period } \\
\text { before the application; } \\
\text { Dual }\end{array}$ \\
\hline $\begin{array}{l}\text { Indonesia } \\
\text { Nationality Law } 1946 \\
\text { (revised 1958) }\end{array}$ & $\begin{array}{l}\text { Jus sanguinis via father; No Jus } \\
\text { soli (only between January 1, } \\
1946 \text { and August 1, 1958) }\end{array}$ & $\begin{array}{l}\text { Residency } 5 \text { years or } 10 \text { if } \\
\text { not continuous }\end{array}$ \\
\hline
\end{tabular}

State legislation regulates the granting of nationality. In addition, norms relating to the nation-state's sovereignty and the local legal and regulation systems determine the nuances in the actual practice of muwātana or citizenship, resulting in variations in content and in practice. Table 8.1 shows the nationality policy of some states to observe important common elements: 1) Jus sanguinis is a predominant condition, while Jus soli is under very limited conditions such 
as when a child has unknown parents (except Pakistan).2) At least in the text, naturalisation eligibility provisions generally appear to meet reasonable standards, such as in the residence period requirement. 3) Gender hierarchy is at work as Jus sanguinis usually passes via the father. Women have limited ability to acquire nationality (other than via marriage) and to transfer it to their children or to foreign spouse. This is an important contributor to the extent of statelessness found in the region. 4) The laws normally demand language proficiency of the country but none explicitly mention religious affiliation. 5) Naturalisation rules are more applicable at the age of maturity; 6) Sometimes states confer citizenship on those who have given exceptional service to the country; and 7) These states mostly do not tolerate dual citizenship.

Despite the diversity among the Muslim-majority states we reviewed, Jus sanguinis evidently dominates as the language of belonging or the link to identity. From Morocco to Indonesia, the states extend from the west to the east in different regions. In Africa: Morocco and Tunisia, Niger and Somalia (also Egypt); in Central Asia and Caucasus: Turkey, Kazakhstan and Iran; in West Asia: Lebanon and Iraq (also Jordan, Syria, Yemen), and in Asia: Pakistan and Indonesia (also Malaysia). ${ }^{2}$ In addition to the diversity in geography, the states represent diversity also in economic development, experience of colonialism, sectarian affiliation, political regimes, and popularity.

Should we conclude that the integration of migrants has less relevance in Islamic countries and that the citizenship concept is essentially associated with the liberal discourse, at least in the civic rights sense? Parolin (2009: 127) observes that citizenship attribution in an Islamic country is commonly via Jus sanguinis by paternal origin and that the sequence of membership is at three levels: in the kin group, the religious community and the nation-state. Further, "most Arab legislation provides for special naturalisation rules for nationals of other Arab countries (co-ethnic preference) and a few for foreign Muslims (coreligious preference) (usually they both imply the same, the confessional aspect)" (ibid.). In the larger picture, the religious lens, rather than the ethnic or the cultural one, appears to define the "other." Parolin concludes that the citizenship rights of minority-others in Islamic countries, "only imply residency rights and nothing more" (ibid.). We noted important similarities in our selected group. The larger evidence suggests that the co-ethnic or co-religious preference (or in combination) dominates in the allocation of citizenship to outsiders. However, it would be relevant to seek more nuanced explanations

2 Malaysia-Jus sanguinis requires both parents to be citizen; no Jus soli. 
that reflect the complexity rather than merely the simplistic dhimmi-based logic for acts of closure.

It is beyond the scope of this paper to explore deeper, for instance, into the specific contexts and the political considerations about the choices of the Muslim states over time. Some factors that stimulated diversity in the policy practice (or convergence) of these states might include phenomena such as pan-Arabism, regional and internal conflicts often associated with the transformation tied to the nation-building processes, and ideological stance against perceived Western imposed standards or institutions. Perrin (2014: 230-1) highlights the relevance of the colonial experience with reference to countries in the Maghreb, "the political use and construction of ethno-religious determinants by the colonial powers during colonization and by the subsequent regime after independence." Some of these states for instance, followed the French model after their independence from colonization such as Egypt, Algeria and Morocco. ${ }^{3}$ The affected population includes local minority groups (including co-religionist or co-sectarian) such as the bidūn (those without nationalities) of nomadic origin in Kuwait, as much as groups from the outside, such as the long-residing Afghans in Iran. She proposes further that, "Reluctance to grant citizenship is rather based on a mix of immaturity in nation-building, of a closed and 'naturalist' - if not ethno-religious-conception of the nation, and of suspicion and fear toward difference and aliens," but she notes that the rejection of diversity is increasingly questioned today (Perrin 2014: 234). Thus, citizenship practice was often a political gesture, linked to interstate relations, national balances and sensitive issues of belonging.

There has been a positive trend for reform in the national legislations in recent years. Two examples of positive reform include Egypt which, in 2004 modified its personal status law to allow women to confer citizenship to their children; and Algeria in 2005 provided that the double Jus soli provision to establish nationality origin applies to both males and females, although the individual must still hold Muslim personal status. The North African states in particular, took measures for granting nationality rights to reduce statelessness and gender inequality. At the broader level, however, we could observe discrimination in the naturalisation law practiced in the Muslim states based on gender, ethnicity (such as Arab race, or language) and religion. Van Waas (2014, 24-30) notes discrimination to be widely common on the grounds of gender, ethnicity, religion and disability in her study on the nationality laws in 17

3 Perrin notes: the French Protectorate used Jus soli (for the indigenous) and Jus religionis to distinguish between the settlers and the natives. The latter made it also possible to separate the Muslims and the Jews from the indigenous. 
Middle East and North African countries (MENA). These violate the International Covenant on the Elimination of All Forms of Racial Discrimination, particularly that the state parties should guarantee the right of nationality to everyone, without distinction as to race, colour, or national or ethnic origin [Article $5(\mathrm{~d})(\mathrm{iii})]$. Moreover, she emphasizes that the "letter of the law can be only half of the story" (p. 31) and that there is an effective gap between rights and the actual practice of granting nationality.

This is evident through the stringent naturalisation provisions that make acquisition difficult as an adult (for example, the use of language that provides for a generally large margin of discretion $)^{4}$ and the neglect of mechanisms for procedural safeguards (such as right to appeal, system of checks and balances and jurisdiction for the courts on nationality matters). As van Waas sums up, "in other words, MENA states' naturalisation practices can be highly challenging, often unpredictable and are especially problematic in those states with large stateless populations" (ibid.).

The religious denomination plays out as an important condition for naturalisation in most of the Muslim countries. Perrin (2014) remarks that although religion is quasi-absent from the citizenship laws of Libya, Algeria, Tunisia, Morocco and Mauritania, the constitutions from "the Great Maghreb" region proclaim a Muslim identity and a belonging to the Arab world (with the official language as Arabic). She adds, "in practice, it (religion) may be important in getting Citizenship through naturalisation and marriage" (p. 233). In our selected group, Lebanon, Iraq, Pakistan and Indonesia apply the Sharia for the family law domain. Therefore, religion could have an indirect effect at least, where states constitutionally provide for an "officially favoured religion" and/ or a religious/Sharia law. Similarly, some states gave access to citizenship to individuals with an Arab origin, even though it was not a legal condition.

\subsection{The Gcc's Citizenship Policies: "The Gate Is Not Open"}

We explore the Gulf Cooperation Council (GCC) states' practice in a closer detail in this section, which is a relatively extreme case in the contemporary context. The six member states namely, Oman, Saudi Arabia, the UAE, Qatar, Bahrain and Kuwait stipulate demanding conditions for naturalisation in the formal text as well. They define themselves as Islamic states and stand out for having large proportion of foreigners of diverse origin in their populations as

4 For instance, Lebanon applies it as a matter of clear policy: "it is not definite that a foreigner who meets [the conditions for naturalisation] will be granted Lebanese nationality" (cited in Frontiers Ruwad Association, Invisible Citizens: Humiliation and a life in the shadows. A legal and policy study on statelessness in Lebanon, 2011: 70; Ministry of Interior, General Questions). 
TABLE 8.2 Nationality law in the GCC states and the length of residence for naturalisation
Law
Residence requirement

\begin{tabular}{|c|c|c|}
\hline Oman & $\begin{array}{l}2014 \text { Nationality Law } \\
\text { (repeals } 1983 \text { law) }\end{array}$ & Residence for 30 years \\
\hline UAE & $\begin{array}{l}1972 \text { Federal UAE } \\
\text { Nationality Law }\end{array}$ & $\begin{array}{l}\text { Residence for } 30 \text { years, } 20 \text { of those years } \\
\text { occurring after January 1, } 1972 \text { ( } 3 \text { years residence } \\
\text { for citizens of Qatar, Oman, and Bahrain; } 7 \text { years } \\
\text { residence for citizens of Arab descent) }\end{array}$ \\
\hline Bahrain & $\begin{array}{l}1963 \text { Nationality Law } \\
\text { (revised 1981) }\end{array}$ & $\begin{array}{l}\text { Continuous residence for } 25 \text { years since } \\
\text { September } 16,1963 \text { ( } 15 \text { years for persons of Arab } \\
\text { descent) }\end{array}$ \\
\hline Qatar & $\begin{array}{l}2005 \text { Law (revised } \\
1961 \text { ) }\end{array}$ & Consecutive residence for 25 years \\
\hline Kuwait & $\begin{array}{l}1959 \text { Nationality Law } \\
\text { by Emiri Decree }\end{array}$ & $\begin{array}{l}\text { Residence for } 20 \text { years ( } 15 \text { years residence for } \\
\text { citizens of other Arab countries) * Required to be } \\
\text { Muslim }^{\text {a }}\end{array}$ \\
\hline $\begin{array}{l}\text { Saudi } \\
\text { Arabia }\end{array}$ & $\begin{array}{l}1954 \text { Nationality } \\
\text { regulations (revised } \\
2004 \text { ) }\end{array}$ & Residence for 10 years but conditions vague \\
\hline
\end{tabular}

"temporary guests," who are indefinitely excluded from integration in the local society with the citizenry. As per their current nationality laws and practice, citizenship is almost impossible to acquire for the resident expatriates. All the GCC states introduced their nationality laws in the 196os and the 1970s, with the exception of Saudi Arabia, which was the first to introduce them in 1954.

The Arab-Gulf states' citizenship policies are exclusionary and involve largely ambiguous provisions. They endorse an ethno-cultural model and in practice, they privilege affiliation to Islam. Table 8.2 underscores a key common element regarding the nationality laws of the Gulf states for naturalisation that are essentially applicable to males: that the primary condition requiring an unusually long period of residence in the territory ${ }^{5}$ effectively discourages naturalisation. Jus sanguinis is the overarching principle in defining eligibility

5 Saudi Arabia, at least in the text specifies a shorter period, and its criteria for qualification including for permanent resident are not clear. 
for naturalisation, by blood and descent only. Jus soli or nationality by birth does not apply, except for instance, if the child is born of unknown parents. In addition, the Arab Gulf states favour Jus sanguinis based on male lineage, where the father can pass on citizenship. The mother can transfer citizenship only in limited cases, ${ }^{6}$ such as in the case of an unknown father or if the father is stateless.

The UAE in $2011^{7}$ and Saudi Arabia in $2007^{8}$ made positive reforms whereas Kuwait became more exclusionary. ${ }^{9}$ The ascription of citizenship on the basis of gender is a common element under the prevailing logic of cultural tradition and is a broader practice also in other Muslim countries, as we saw earlier. Naturalisation access for a foreign woman is through marriage. Native men can pass nationality to foreign spouses, however conditions might vary in different GCC countries and the process is not always transparent. A native woman cannot pass her nationality on to a foreign husband..$^{10}$ The woman might also lose her Gulf-citizenship and privileges. In addition, the Gulf states do not tolerate dual citizenship unless specifically approved.

A review of some historical and socio-cultural factors might help us to understand the Arab-Gulf states' citizenship policies. As Longva (2000) suggests, "contributing to the way citizenship is conceptualized and put into practice is: history, tradition and above all, the circumstances under which the state is created and legitimacy is maintained" (p. 97). Longva writes that the notion of citizenship (her work concerns Kuwait but is broadly relevant to the rest of the Gulf region) "is implicitly but nonetheless inherently conceptualised by most Kuwaitis not on terms of universal and abstract rights and duties but in the deeply cultural and particularistic terms of identity and loyalty" (p. 196). The Gulf States were essentially tribal and traditional desert societies that transformed in a rapid fashion to wealthy, modern nations from the turn of the 1960s. Citizenship in the Arab-Gulf States is largely based on the jinsiyya principle, as "an identity or membership linked to the territorialized state/and a community" (p. 193). Citizenship and access to it in the Gulf is hence generally

$6 \quad$ Qatar does not let mother confer citizenship to children without exception, even if the result is statelessness.

$7 \quad$ UAE allows a child (boy or girl) of native mother and non-national father to apply for citizenship after 18 years.

8 Saudi Arabia allows sons of a native mother and non-national father to acquire citizenship at the age of majority.

$9 \quad$ E.g., it removed a clause that previously allowed children of Kuwaiti mothers and stateless fathers to acquire nationality.

10 Omani law reduced the residence period requirement for a foreign man married to an Omani to 15 years, but subject to the conditions that the marriage occurred with prior approval of the Ministry of Interior and there is a son born from the marriage. 
conceptualised on creed/or a religious-ethno-cultural basis. In addition to this, important state-centred explanation of practices in the region, Longva (2000) further suggests that citizenship also implies entitlement rights in an "entitlement state" (including political rights in the case of Kuwait) (p. 193). The entitlement focus of citizenship in the GCC is an accrual of membership in an autocratic welfare state, in contrast to a participative model that is more prominent elsewhere. ${ }^{11}$ The current Gulf regimes maintain the "ruling bargain" and sustain their political legitimacy, by maximal wealth distribution within a limited native membership to ensure citizen loyalty. Thus, the Jus sanguinis nationality laws effectively maintain citizenship as an exclusive privilege of the local-national.

An important problematic aspect with respect to naturalisation in the region is that the implementation of the nationality rules is a non-transparent process. The royal authority or the relevant agency (normally the Ministry of Interior) grants citizenship usually by a highly discretionary exercise. Even if the procedure for naturalisation exists in the legal text, its application in practice is hazy. In addition to the residency period, other general conditions include knowledge of Arabic language, good character and sufficient financial capacity. However, there is ample anecdotal evidence about numerous cases where expatriate applicants never succeeded in their applications for naturalisation. This was despite their qualifying on all the specified criteria as per the local rules including long term residence in the respective host country and Arab descent with affiliation to Islam. This was a familiar story during earlier fieldwork in the region. Typically, applicants for naturalisation waited for an unspecified number of years to receive a decision after the submission of their files.

On the other hand, there are also successful instances of citizenship acquired via the more discretionary exercise of authority, such as an Indian cook who had worked for an important family in Oman for many decades being rewarded with citizenship. Exceptions therefore, include hand-picked individual cases and by a selection process that is non-transparent. There are still no clear rules or practices ${ }^{12}$ in the Gulf region as to qualifications and procedures for naturalisation. For example, naturalisation criteria in Saudi Arabia does not mention religion, the Basic Law requires a citizen to be Muslim. In Bahrain, the

$11 \quad$ Allegedly associated with the Western notion of the citizenship

122005 Amendment in Qatar introduced eligibility guidelines for naturalisation, prior to which, the law only provided that that the Emir would grant naturalisation at his discretion. 
text mentions that the person must be of good character, with a good command of Arabic, and have real estate registered in his or her name in Bahrain. Permission can only be granted from the ruler of Bahrain. The lack of consistency and common rules for the granting of naturalisation is glaring. In contrast, there is a clear perception amongst both the expatriate and the national populations in the region that naturalisation is an unlikely phenomenon. Hence, stories, such as the Syrian in Kuwait cited earlier, of individuals resorting to indirect and false methods to acquire citizenship might not surprise us much. On the rare occasions of successful naturalisation, the process and the information remain a black box. The news is usually sensitive and kept confidential. Hence, information about the successful cases of citizenship acquisition in the Gulf is unclear. The applicable criteria, as well as the actual numbers in a specific period are rarely made accessible to the public.

Moreover, the Gulf States have also used naturalisation strategically as a selective instrument on several occasions, to manipulate the ethnic and nationality composition in the population on the basis of geo-political calculations. The Bahraini regime's controversial practice to grant nationality to some Sunni-denomination communities to undermine the Shia dominance in the local population is a prominent example. It supposedly gave nationality liberally to the expatriates of Pakistan and of other origins at specific times in the past decades. Kuwait also used this strategy in the 196os and the 1970s to naturalize mostly Sunni tribes from other parts of the Arabian peninsula, "as a counterweight to the urbanised Kuwaiti liberals, leftists and Arab nationalists" (Kinninmont 2013, 53). The Palestinian population ${ }^{13}$ spread throughout the Gulf region is another example of the selectivity of the nationality grant. Other instances of the GCC states' wide scope for arbitrary exercise over citizenship used against their own populations include, the cases of Kuwait's Bedouins and Bahrain's revocation of some its nationals' citizenship since the protests in 2011 (the Shi'a dissenters). Granting nationality is clearly the discretionary domain of the supreme authority vested in the executive power of the Ruler. In a more recent trend, the GCC states have extended "temporary citizenship" to sports-professionals from the African, Central Asian or other developing countries (including to individuals with desired talents in other domains). While the practice again exemplifies the instrumentalist aspect to grant citizenship to foreigners, it also underlines its essential exclusionary element. It is an example of selective citizenship as a temporary grant, in exchange for the

13 The Arab League put a ban on naturalizing Palestinian refugees in the Arab countries to avoid undermining the right of return cause. 
individual's anticipated value to enhance the Gulf nations' performance and reputation records in the international arena. The state withdraws citizenship when the player leaves the sports team.

Therefore, the GCC states grant citizenship highly selectively. "No GCC country has made any significant policy changes addressing the situation of their long-term and second-generation migrants since the modest changes in citizenship law of Saudi Arabia" (Baldwin-Edwards 2011: 43). The GCC states have actually tightened their nationality rules.

\section{$4 \quad$ Conclusion}

Random comments such as, "In a Muslim country, citizenship is impossible to acquire as a foreigner!" are indicative of a relatively pervasive impression as if it were a self-explanatory phenomenon. I heard it often from the expatriates of different nationalities during my doctoral fieldwork in the Gulf region, where naturalisation is especially arbitrary and the local regimes are authoritarian. This general impression that naturalisation is difficult and officially unwelcome to a non-Muslim resident applies to most Muslim-majority states.

We looked at naturalisation provisions from a mixed set of 18 Muslim-majority states. While the laws and provisions appear reasonably fair as per international norms (the six GCC states are an exception, which impose more extreme requirements), the actual citizenship acquisition for foreigners is difficult and unpredictable. In general, the naturalisation phenomenon in Muslim countries shows a less objective basis with an emphasis on Jus sanguinis and co-religious preference. Most nationality laws do not mention Islam in their official criteria, but apply it in effect. Perrin's $(2014,234)$ observation concerning the Maghreb states in North Africa is applicable to most of these states: "While express mentions of Arab ethnicity or Islam are scarce on the books, they seem to be important criteria when granting citizenship.'

However, we do not see a uniform rule or a consistent practice among Muslim states. Foreign Muslim residents are also not granted naturalization more liberally, except when the host state favoured for other reasons (for instance, to influence the demographic composition in the population). In addition, it might be easier to explain the Arab-Gulf states' much harsher rules as due to the nature of their absolute monarchies. Moreover, their policies and practices on naturalisation and citizenship emphasize a priority to exclude, and to maximize their flexibility and power over foreign workers. Yet, such discrimination is no different from examples that involve non-Muslim states both in the past 
(Germany) and in the contemporary period (Japan) where restrictive naturalisation is on a highly selective basis.

The notion of citizenship and integration of the "outsider" in the classical texts have largely suggested that full membership should be limited to the adherents of Islam. However, the larger textual body and Muslim practices over time have shown some provision for flexibility and accommodation to reflect changing societal and ethical concerns. The Al-Azhar Declaration and significant scholarship have asserted that Islam or the Shari'a does not preclude plurality. Further, Islam in its practice is not monolithic and history gives us ample proof of its adaptation. Therefore, the invocation of Islam's supposed reluctance to integrate the Other to explain the contemporary Muslim states' proclivity for restrictive naturalisation policies would be insufficient. We observe an amount of commonality in the Muslim states' naturalisation practice with a tendency to exclude the outsider. However, a more careful look already suggests more consideration of politics in the discrimination.

States' choices in their local contexts, including for potential reform, reflect exigencies as much as doctrinal inspiration. For example, the Arab-Gulf region shows variations in the practice of granting citizenship and reflects the local regimes' delicate ruling bargain and their perceived imperative for greater control over the foreign population to maintain their legitimacy. We see evidence of randomness in granting citizenship involving, for instance, the native Bedouin in Kuwait as well as expatriates (whether Muslim, Arab, or other faith and identities). To conclude, this research affirms the evidence that Muslim states' naturalisation provisions incline towards highly selective practices, but they also show a certain receptivity to diversity.

\section{Bibliography}

Albarazi, Zahra and Laura van Waas. 2014. "Transformations of nationality legislation in North Africa." In Routledge Handbook of Global Citizenship Studies, edited by Egin Isin and Peter Nyers, Abingdon, Oxon: Routledge. Chap. 17

Baldwin-Edwards, Martin. March 2011. "Labour immigration and labour markets in the GCC countries: national patterns and trends." Research Paper, LSE Kuwait Programme on Development, Governance and Globalisation in the Gulf States. No. 15.

Fetni, Hocine. 2008. "Citizenship divided: Muslim subjects, Arab citizens, democratic dilemmas." In The Future of Citizenship, edited by Jose Ciprut. Cambridge, Massachusetts; London: MIT Press. pp. 167-189.

Hourani, A.H. 1947. Minorities in the Arab World. London: Oxford University Press. 
Isin, Engin. 2012. "Citizenship after orientalism: an unfinished project." Citizenship Studies 16(5-6): 563-572.

Isin, Engin and Peter Nyers, eds. 2014. Routledge Handbook of Global Citizenship Studies. Abingdon, Oxon: Routledge.

Kanchana, Radhika. 2016. PhD thesis, Political Science. "The expediency of the contemporary guest worker migration policies that curb mobility: The Arab-Gulf countries and the Indian migrants." Institut d'Études Politiques de Paris (Sciences Po), France.

Kinninmont, J. 2013. "Citizenship in the Gulf." In The Gulf States and the Arab Uprisings, edited by Ana Echague. Spain: FRIDE \& the Gulf Research Center. pp. 47-57.

Kiwan, D. 2014. "Emerging Forms of Citizenship in the Arab World." In Routledge Handbook of Global Citizenship Studies, edited by Engin Isin and Peter Nyers. Abingdon, Oxon: Routledge. pp. 307-316.

Longva, A. 2000. "Citizenship in the Gulf States: Conceptualization and Practice." In Citizenship and the State in the Middle East: Approaches and Applications, edited by Nils Butenschon, Uri Davis and Manuel Hassassian. Syracuse: Syracuse University Press. pp. 179-197.

Martin, R. 2005. "From Dhimmis to minorities: Shifting constructions of the non-Muslim Other from early to modern Islam." In Nationalism and Minority Identities in Islamic Societies, edited by Maya Shatzmiller. Montreal and Kingston: McGillQueen's University Press. pp. 3-21.

Parolin, G. 20o9. Citizenship in the Arab World. Kin, Religion and Nation State. Amsterdam: Amsterdam University Press.

Perrin, D. 2011. Immigration and citizenship law in the Maghreb: Turning aliens into citizens. EUI Working Papers. RSCAS, No. 4 O.

Perrin, D. 2014. “Citizenship struggles in the Maghreb.” In Routledge Handbook of Global Citizenship Studies, edited by Engin Isin and Peter Nyers. Abingdon, Oxon : Routledge. pp. 230-239

Shatzmiller, Maya, ed. 2005. Nationalism and Minority Identities in Islamic Societies. Montreal \& Kingston, London, Ithaca: McGill-Queen's University Press.

Van Waas, Laura. September 2014. "A comparative analysis of nationality laws in the ME NA region." Report of the Middle East and North Africa Nationality and Statelessness Research Project. Tilburg University Statelessness Programme.

\section{Other Documents}

Asia News (March 3, 2017) "Al-Azhar: pluralism and citizenship at the basis of Islam. But a civic state is missing." 
Pew Research Centre. April 6, 2017. Michael Lipka and Conrad Hackett. "Why Muslims are the world's fastest-growing religious group." < https://www.pewresearch.org/facttank/2017/o4/o6/why-muslims-are-the-worlds-fastest-growing-religious-group/>. Accessed August 2017.

Pew Report. 2013. The World's Muslims: Religion, Politics and Society. <http://assets.pe wresearch.org/wp-content/uploads/sites/11/2013/o4/worlds-muslims-religion-poli tics-society-full-report.pdf $>$. Accessed August 2017. 